\title{
From Sustainable Under-Development in the Pioneer Fronts: The Case of Benoue Agricultural Production Area, North Cameroon
}

\author{
Abdoulay Mfewou ${ }^{1}$, Fon Dorothy Engwali ${ }^{2}$, Sevidzem Silas Lendzele ${ }^{3 *}$ \\ ${ }^{1}$ Teacher-Researcher, University of Dschang \\ ${ }^{2}$ Enseignant-Chercheur, Université de Dschang, Cameroun \\ ${ }^{3 *}$ Researcher,University of Dschang Faculty of Science P.O Box 067 Dschang, Cameroon.
}

\begin{abstract}
Population migration started around the end of the colonial era by the independent state and this was organised and planned in North Cameroon. Populations in the overcrowded areas of the Far North region, which is more arid and less favorable for agriculture, were accompanied by development projects that were responsible for overseeing the recolonisation and exploitation of its important agricultural and forestry potential. The pastoral zone is located south of this region. These areas, which are more watered, offer diversified agricultural and pastoral potential, ranging from lowlands suitable for the cultivation of muskwari (backyard sorghum) and rice, to land that is suitable for rainy food crops and cotton. More than half a century after the start-up and the end of these projects, and following a real arrogation of migration by the target populations, one would stake against the known agricultural potential of the zone, to an effective prosperity of "small farmers" fixed on this site. Due to the limited available literature regarding the constraints to the development of the last decade and the recent strong media coverage of social tensions on land and food insecurity, these issues have led us to formulate the hypothesis of a "sustainable underdevelopment" of the area. The results of this present surveys and synthesis of the archives reveal that socio-economic and administrative factors that hinder local development worsenand destabilize any innovation over time. The drivers of this underdevelopment are not unrelated to the inability of development projects or local government to integrate human and the migrant into the project of local development, but also to secure its productive resources at longer term.
\end{abstract}

Keywords: Agriculture, Pioneer front, Underdevelopment,North Cameroon.

\section{INTRODUCTION}

The population of Cameroon is diverse with about 1687959 inhabitants, agricultural land occupying about $66090 \mathrm{~km}^{2}$ of its total surface area and vast livestock areas which make it this country to stand for the most important production pools of Central and West Africa. The development projects initiated by colonization before independence then by the Cameroonian administration (1960) centered this opportunity. The goal was to develop the cultivation of cotton, to seek food security and to meet-up with the food demands of the surrounding towns. This objective was initially tested in the northern part of the region then ultimately spread throughout the region through the multiplication of development projects inspired by the "productivist" model.

The Cotton Company encouraged by the administration appears to be "a real engine for the development of the zone", which has intervened in the spread of animal traction and the progressive organization of producers in groups of common interest for the production of cotton seed. It ensured the supply on credit to producers equipment's for the cultivation of cotton and then simultaneously for food crop until the advent of the last cotton crisis that occurred in the middle of the year 2000 . Technical supervision of rural activities has been progressively strengthened by policy orientations centered on openness to development: development of rice-growing areas, opening of penetrants to encourage the collection and disposal of products and relations between cities and countryside.

Today, some settled migrants, are confined to strategic locations where they practice the cultivation of cereals, peanuts or cotton. A second category consists of migrants who engage in peri-urban agriculture on both banks of the river Benoue and cultivate market gardening products throughout the year to supply the town of Garoua (North Cameroon). Others, located in irrigated perimeters, practice 
irrigated rice farming in a context of precarious land tenure. The latter category cultivates rice in a well-developed production area, benefiting from infrastructure and support from numerous projects to develop the sector. However, these "small family production units" located at the crossroads of central and western African states continue to import from Asia. More than $90 \%$ of the national rice consumption is handicapped by this issue of foreign rice brand which is characterized by instability and insecurity.

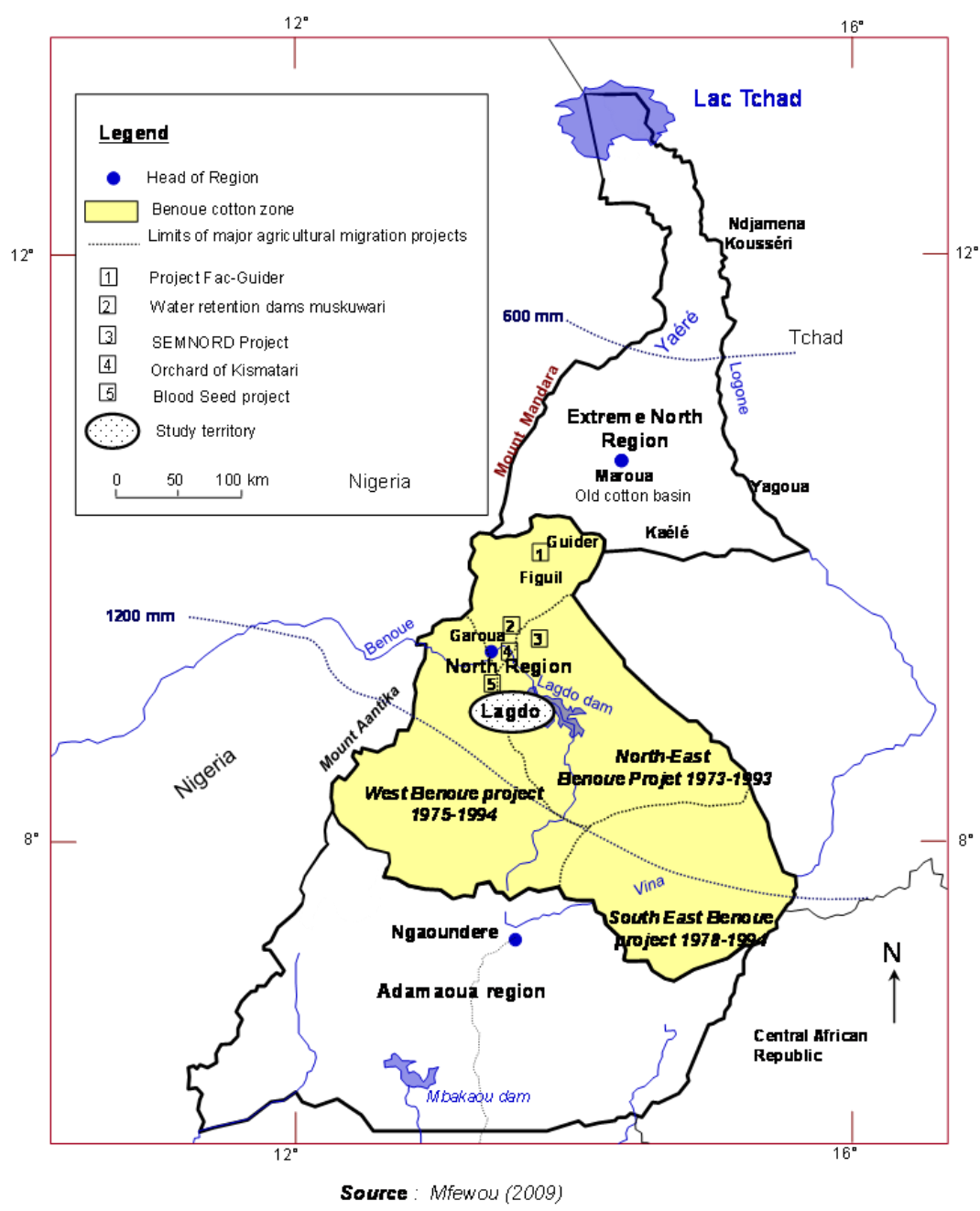

Fig1. Map showing areas of agricultural projects in the Benoue valley

It is to analyze the paradoxes of this system of rice production that we are interested in the territorial functioning of the irrigated perimeters of Lagdo (Gounougou, OuroDoukoudjé, Dingale and Bessoum) where land issue seems to be one of the constraints to the development of the sector.

The analysis of bibliographic and field data with focus on Northern Cameroon in terms of development projects, population migrations, management of land and natural resources and the functioning of family farms, specify the nature of the additional investigations to be carried out. This investigation was made by surveys of 956 heads of farms in the irrigated perimeter of Lagdo, including the villages of Gounougou, OuroDoukoudjé, Dingalé and Bessoum. This information was complemented by interviews with different resource persons and strategic groups involved in the management of irrigated perimeters: official project managers; Chiefs, customaries ${ }^{1}$ and religious leaders.

Analysis of the data included:

- Clarification on the spatio-temporal modalities and socio-economic processes of agricultural migration,

Analysis on the systems of activities and the way of life of migrants and,

- Cross-checking of information to propose sustainable development paths for farmers. 


\section{The Migration Process in North-CaMeroon}

\subsection{Cotton: A Historical Factor in Agricultural Migration}

The main task of the projects carried-out in North Cameroon was to diversify and increase food crop products with the intentions of fighting against food inadequacy, developing cash crops (groundnut, cotton etc) and accompany populations towards a more monetarized economy.

The attractive world prices of cotton in international market, encouraged decision-makers of the French Company for the Development of Textile Fibers(CFDT) to extend its cultivated areas. As early as 1951, the CFDT set up a technical and hierarchical structure with a network of administrative and technical personnel in the region. The cultivation of cotton increased from 50,000 to 100,000 hectares (1953), reflecting an enthusiasm for this crop. The purchase price from planters was $30 \mathrm{Fcfa}^{1}$ $/ \mathrm{kg}$ in 1966, accompanied by a seed premium which made it more attractive as compared to other cash crop (groundnut). Cotton became the first cash crop in the Sudano-Sahelian zone. Fifty years after independence, arable land accounted for about $23 \%$ of the total area and about half was actually developed. The degradation of natural resources and the precarious living conditions of populations are the main constraints in this area. Production is estimated at 240000 tons. The number of workers is on average 3 to 4 individuals per ha.

The national livestock population is estimated at 6,000,000 head of: $37.5 \%$ in the Far North, $33.9 \%$ in Adamaoua, $11.6 \%$ in the North, $8 \%$ in the Northwest, $6,3 \%$ in the East and $2.7 \%$ in the West. Based on cattle breeds, the zebus constitute $98 \%$ of the livestock. They are the zebu Peuhl of Sahel (North and Far North), White Mbororo zebu or White Fulani or Akou (North, Far North, and Adamaoua, West and East), Red Mbororo zebu or Red Fulani or Djafoun (North, Far North, and Adamaoua, Northwest, West and East), Goudali zebu (Adamaoua, East, and Northwest). Milk production was $96.5 \mathrm{~kg} /$ year and carcass yield was $146.2 \mathrm{~kg} /$ year (MINADER-Cameroon, 2016). Consumption is expected to grow naturally as a result of population growth.

It was observed that the archives of the Cameroon Cotton Development Corporation (SODECOTON) revealed that cotton development in North Cameroon was carried out without the use of fertilizers. In order to do this, it was necessary to exploit better land, and in this respect technical guidelines encouraged the mobility of cotton-growing populations to the fertile plains of the far north of the country. The complement concerned the introduction of productive varieties and the setting up of a device to enable the highest admiration for the technical itinerary. The CFDT organizes the distribution of credits for the purchase of equipment and coupling, which will contribute to the development of plowing thanks to harnessed cultivation. This innovation will help to improve the average yield of cotton seed which revolves around $500 \mathrm{~kg} / \mathrm{ha}$, with a production record of $845 \mathrm{~kg} /$ hain 1969.The Plains of Far North occupied 4/5 of the seeded areas (SODECOTON, 1975).

However, the poor weather conditions linked to droughts of 1973 generated a cotton crisis which led to the collapse of cultivated areas (3/5), while the price of cotton in international market doubled in the same year. The CFDT changed its agricultural policy by proposing cotton cultivation intensification using organic fertilization and new techniques which wereincited during the administration of crop protection products. A 8 per cent cotton harvest in cultivation areas in 1967 increased to 22 per cent in 1968 and 30 per cent in 1969, followed by yields of 596kg / ha in 1969 and $986 \mathrm{~kg} / \mathrm{ha}$ in 1975 (SODECOTON, 1975).

Land tenure problems were foreseen in 1965 by the project's decision-makers "it is certain that the allocation of land to migrants in already occupied areaseven if the density remains low and must be preceded by very serious studies [...] It would be desirable that, in 1966, a mission of specialists should be made available to the Federal Inspector for the study of the problem of land and rural migration ... " 2 . However, this in-depth study no longer took place and the land problem which was not explored was generally over flooded or even hidden in all the projects that will emerge thereafter. It was on this incomplete assessment that all agricultural migration projects in Benue (North Cameroon) were elaborated.

\footnotetext{
${ }^{1}$ leuro $=655 \mathrm{Fcfa}$

${ }^{2} \mathrm{Bdpa}$, 1963. Problèmes de développement rural dans le Nord-Cameroun. Paris, 150 p. Multigraphié

International Journal of Research in Geography (IJRG)
} 


\subsection{Spatio-Temporal Processes of Mobility}

\subsubsection{Internal movements}

In this system, the migrant does not change political or social context, always stays with his family, not disoriented, and has the opportunity to acquire land, participate in religious ceremonies. Moving within the same ethnic space is not a matter of migration, but rather of internal mobility. This is the case for example of the Keda, a landless peasant among the Mafa, where the elder inherits part of the land and the youngest is a successor in keeping the concession while the trainees have the duty to migrate.

This migratory movement is observed in the Far North province by the gradual descent of the surplus of the mountain population towards the mountain foot. But the land capacity of the mountain foots and plains of this province has proved incapable of absorbing all the descendant flows. Clashes between peasant groups multiplied because of excessive densities $\left(200-230 \mathrm{hab} / \mathrm{km}^{2}\right)$ and poor development forced the population to move further.

\subsubsection{B. External movements}

In this type of movement, the conditions of installation are different from the internal movements. Here, the migrant undergoes the prerogatives of the host populations. He is placed under the rule of a traditional chief, whose local language which at times is not understood by the migrant. He does not participate in the decisions taken by the host village community. He rarely acquires social autonomy as in its ethnic space. If the chief grants him the right to exploit the land, it is often the limited plots, obligated in return for a benefit in kind or royalty. The first migrants settle in close proximity to a relative already in place, never very far (about $100 \mathrm{~m}$ ). Then gradually they fill the colonized space, the others coming to settle in this same space seek for their own place a little farther from the former migrants. Dissatisfied with living conditions or the saturation of space, some migrants try their luck elsewhere in the less populated areas here; they play the role of pioneers. Such a process of successive displacement generates complex migratory currents.The migratory phenomenon recorded between 1955-1965 is represented by the descent of migrants to the relatively under-populated plains. Ethnic groups that recorded a high concentration in the Far North were mainly: Guiziga, Moundang, Toupouri and Massa and Mbaïnama (or Guidar).

The years 1965-1975 are marked by the process of accelerating the mobility of the population towards the plains of Benue. In this movement, the study task is to organize their settlement. The migratory flow necessitated care until the land was occupied, but the migrant remained under the dominion of the traditional chief known as the Lamido. There is a real misunderstanding, which will be maintained afterwards. Migrants believe that they are the privileged ones of the state which has itself displaced them and on pioneer sites, on "vacant lands". They can only withhold their settlement from the administration and believe they have no account to give back to anyone and not even to the small local chiefs, whose development projects geared towards the follow-up of migrantssince 1950, disappeared after chieftaincies.

The state withdrew and the administration no longer responds to their plead however, CFDTSodécoton also needed the chiefs in the 1970s to organize the vast cotton sales (Boutrais, 1971). The migrants found themselves alone against the Lamibé and with the equipment of notables who intend to benefit from their enrichment from the sale of their cotton (Seignobos, 1996). This situation increased psychodrama and violent conflict.The sons of better-educated rural indigenes are now trying to play the role of committed elite in recognising the right of ownership and occupation by relying on national legislation and treating state affairs. Geographically, the ethnic composition of the settlement was greatly modified by the different phases of arrivals and integration of migrants (Toupouri, Moudang, Guiziga, etc.). The Foulbé population reduced to a small proportion (32\% supremacy basedon infrastructural potential). Before the arrival of the first migrants and even later, the Fulani of the region of Ngong, Lagdo and Bibémi did not cease to leave in the Central African Republic to open small businesses in all the localities of the West of the Central African Republic. The pioneer front on the Garoua-Ngaoundéré road was enhanced by the arrival of migrants. In 1981, the population was 20.5\% made up of the Fulani indigenes however the first migrants were- the Mboum, Laka, Ngambaye (23\%) and migrants from the Plains of Far North around $45 \%$ of this population was 4436 
people (1119 families) out of a total of 9898 inhabitants which consisted of mainly Mbaïnama (1165), Moundang (1027), Toupouri (994), Massa (709) and Guiziga (623) with few Montagnards which were made up of about 415 people (11.5\%) still continuing migration (MEASVB, 1982).

Beyond 1981, migrant arrivals were observed on their own initiative. This form of migration grew over time. The migrants colonize the edges of the national road mainly for housing and agriculture and occupy vast areas of land a little distant from their areas of residence. In this kind of movement it is always difficult to quantify the number of newcomers and those who have left. The village of Ngong plays an important role in the redistribution of the arrivals. This new spontaneous mobility is oriented towards the land to be cleared with focus on usually made on virgin land. These settlement communities became their true villages (Tongo, Kaiwan, Rabinga, Boumedjé, Gouna ...).

\subsubsection{Seasonal and temporal movements}

Seasonal movements for agricultural follow the same orientations as the so-called external migrations. The seasonal migration mainly concerns the Pagans, who come to work among the Muslims of the plain. After their own agricultural work, they emanate in small groups to weed the plots of cotton. They are mainly hired for the transplantation of sorghum "Muskuwari". This period falls in September or October according to the variation of the climate. A poor agricultural harvest of the year before accentuates their departure and this affect almost all families. Conversely, their number decreases when crops are good. The male population is highly mobile ( $60 \%$ of men) relative to that of their female counterparts. After transplanting, most of these agricultural workers return to their villages of origin to make their own harvest or threshing of sorghum.

During the long dry season, farmers are usually unemployed and spend most of their time in carryingout their social obligations, huts construction, straw roof and crafts for the production of agricultural equipments (hoe, basket ...). Some migrants sell fire wood and others sell and carry drinking water in the towns of the northern province (Garoua, Pitoa, Ngon ...). Others sell fodders (Ficussycomorus, Faidherbiaalbida, Echinochloastagnima) in Garoua and Maroua markets, especially seasonal migrants from Mayo-Tsanaga. These fodder varieties vary in average i.e. 3.5t / day (in the dry season and more than $7 \mathrm{t} /$ day and in the rainy season with a price which also varies on average from 10 to 100 FCFA / $\mathrm{kg}$ (Ngo Tama et al, 2007).

Temporary movements are observed mostly at the end of dry season. Small towns recruit workers for non-agricultural work and some earn small semi-stable jobs: retailers, guard services and housekeeping. They return home from farm work in the next rainy season. International (neighboring) immigration has increased since the construction of the hydroelectric dam in Lagdo, which has made this reservoir a very suitable area for fishing activities. About $94 \%$ of immigrants from abroad are from Chad and Nigeria and they practice fishing, agriculture and market gardening in varying proportions (Beauvilain 1989).

\subsubsection{The New Form of Migration Beyond North Cameroon}

The new generation of migrant families in Northern Cameroon generally refuses to consider agriculture as their main activity as their parents. After their successful schooling or not, these young people move massively towards the capital of Cameroon in search of greener pastures "I will not want to be like my father who cultivates an unsafe ground where the lamido can hunt him any time ". We have observed that public transport agencies are always full of passengers and the railway line in Ngaoundere has become the main route acting as a form of continuous migration source for those who do not yet have the means of transport.They leave their village in small groups of two or three. The train is always full of passengers and those who do not have transportationmeans and engage in the sale of drinking water in bottles while others carry passengers' luggage to make money, the latter negotiate Passengers for travel agencies. These young people travel to find jobs in informal activities. They nourish a large number of 'rescuers' (vendor on the run).

Upon arrival, some carry passengers 'bags, others are recruited in private security agencies ${ }^{3}$ as security guards, the third group become retailers of shoemakers' clothing and footwear which they sell in the city and the last groups struggle without going out. Every day, they return to travel stationsthat

3 agence de sécurité privée : Africasecurity, Daga...

International Journal of Research in Geography (IJRG)

Page 12 
serves provide shelter for them. Infact, the return of migrants to visit their relatives in the village of origin is more frequent during festiveperiods usually at the end of the year and this visit always causes other spontaneous movements of new set of candidates. However, failure in these informal activities often results in their return to agriculture of which in northern Cameroon it still face a lot of problems even for peasants with annual incomes above 1,000,000 FCFA. They no longer enter their village of origin but rather in villages that occupy different levels of this vast migration.

\section{INSTALLATION IN IRRIGABLE AND "UNDER DEVELOPMENT" ZONE}

\subsection{Factors Contributing to the Failure of Irrigated Crops}

At the irrigated perimeter of Lagdo, the mechanization of cultivation practices such as plowing, harrowing, burial of fertilizers and organic residues was managed by the Mission d'Etude and the association of peasants or a group of common interests (GIC) before the economic crisis of 1990.Hydro-agricultural infrastructure is currently completely degraded. Establishments of water wells are very limited and when they occur, monitoring and renovation are almost absent causing people to distant themselves in order to have portable water. The amplification of land conflicts between actors has contributed to the failure factors of agricultural production. The land status leaves a permanent vacuum of ownership, the migrant can lose his plot if the land manager has another interest on the plot and considers it more profitable (Table 1).

Table1. Land tenure at the irrigated perimeter of Lagdo

\begin{tabular}{|l|l|l|l|l|l|}
\hline Villages/ status & Gounougou $(\%)$ & $\begin{array}{l}\text { OuroDoukoundjé } \\
(\%)\end{array}$ & $\begin{array}{l}\text { Bessoum } \\
(\%)\end{array}$ & $\begin{array}{l}\text { Dingalé } \\
(\%)\end{array}$ & $\begin{array}{l}\text { Total } \\
(\%)\end{array}$ \\
\hline Owner & 6 & 80 & 94 & 12 & 61 \\
\hline No-owner & 89 & 1 & 2 & 99 & 31 \\
\hline Undecided & 5 & 19 & $4 \%$ & 0.1 & 9 \\
\hline Number of respondents & 100 & 100 & 100 & 100 & 100 \\
\hline
\end{tabular}

Source: Survey of a sample of 956 farm managers

We observed that farm heads $(60 \%)$ of the villages of Ouro-Doukoundjé, Béssoum and Dingalé consider plot allocation forms as a land title and updates them whenever they are threatened with expropriation. The peasant knows very well that it is not a complete valid document, but a true land registration which is in the form of an attestation. Such a document is not necessary because in these villages, it would be assimilated to an asocial approach. However, this land allocation forms allow administrative argumentation of a file. In Gounougou, there is a small percentage of peasants who think they are owners. This small percentage is explained by lack of possession of allocation documents by these peasants. The study vision began with the allocation of plots and allocation of land documents in the first three villages but Gounougou did not benefit from this fact sheet. Legally, considering right of property is worthless and the peasants can still be dislodged and above all in compliance with the land legislation of 1974. Nevertheless this paper can serve as a support document for the establishment of title.

In the region, attempts are made to remove land transactions made through oral means (Seignobos, 2000). There are more and more deliberations of traditional justice, a kind of intermediate act between property and right of use, on papers with a buffer to the arms of chiefdom and worded in anonjuridical French. This tandem would be in line with certain projects (DPGT-TERDEL) which in the same light of Seignobos (2000) seek to secure land tenure through a "codify without legislating".

\subsection{Main Crop Yields on the Irrigated Perimeter}

The overall production of rice in the production units of the area depends on yields and total area sown (Table 2).

Table2. Rice yield ( $\mathrm{kg} / \mathrm{ha}$ ) for the 2009 crop year

\begin{tabular}{|l|l|l|l|l|}
\hline Cultures/Villages & Gounougou & OuroDoukoujé & Béssoum & Dingalé \\
\hline Rainy season rice & 3700 & 3600 & 3500 & 3100 \\
\hline Dry season rice & 3400 & 3500 & 3300 & 3000 \\
\hline Processed rice & 3200 & 1300 & 1100 & 2200 \\
\hline
\end{tabular}

Source: Survey of a sample of 956 farm managers 
The recorded yields of rice show a slight variation from one village to another. Production in the rainy season is significantly higher than in the dry season. Our observations showed that land conflict is not a limiting factor in the production of rice but rather a weakening of the social organization of the sector. The cultivation of sorghum practiced outside the irrigated traps produce 1100 to $1500 \mathrm{~kg} / \mathrm{ha}$ (2005/06 campaign).

Table3. Yield ( $\mathrm{Kg} / \mathrm{ha}$ ) of muskuwari and Sorgho at the studied perimeter of Lagdo

\begin{tabular}{|l|l|l|l|l|}
\hline Speculation/village & Gounougou & Ouro-Doukoujé & Béssoum & Dingalé \\
\hline Sorghum & 1100 & 1200 & 1200 & 1200 \\
\hline Muskwari & 1500 & 1200 & 1200 & 1000 \\
\hline
\end{tabular}

Source: 2009 Agricultural Campaign

The presence of sorghum in crop rotation makes it possible to spread the agricultural activity and to leave the risks linked to climatic hazards. It is a basic food crop and currently accounts for over half of cereal production. Generally, each farmer sells the surplus of his crop to meet the daily need.

\subsection{The Impoverishment of Migrants in the Irrigated Perimeter: An Observation}

Faced with low selling prices (Table 4), and reduced overall production, the local population is still living in poverty.

Table4. Average prices of different agricultural products at the Lagdo market

\begin{tabular}{|l|l|l|}
\hline Speculation & Selling priceFcfa/kg & \\
\hline Cotton & 170 & - \\
\hline Corn, sorghum, muskwari & 9000 & 95 \\
\hline Groundnut & 17000 & 95 \\
\hline Cowpea & 16000 & 95 \\
\hline Rice paddy & 10000 & 80 \\
\hline Onions & 21000 & 60 \\
\hline
\end{tabular}

Source: 2009 Agricultural Campaign

Indeed, their limited financial capacity generated from agricultural activities does not allow them to develop social infrastructures or to take over the management of those bequeathed by the State or development projects. Several social infrastructures are not within the direct reach of the population. An individual needs to cover $60 \mathrm{~km}$ on a motorbike with a lot of patience to arrive at the hospital in the town of Garoua.The rice fields remain mosquito swarming reservoirs. These vectors of malaria are never visible during the day and become abundant at dusk. Malaria remains endemic and has the highest morbidity rate, especially in children 0 to 5 years of age. Onchocerciasis is frequent in the waters upstream of the reservoir (Djipodé, Ouro-Kessoum, Mayo-Baï, Bakjaolé). Between the villages, the enrollment ratios vary between $45 \%$ in Dingalé and $60 \%$ in Gounougou. In addition to this, there exist difficulties in land confrontation between the different actors.

\subsection{Towards Development Revival}

Faced with land conflict which is one of the limiting factors of development, mediations actions initiated by the DPGT-TERDEL project and the diocesan committee within the territories can be supported by the administration. This mediation can normally spread throughout the region to ensure sustainable agriculture. Securing land in rural areas could induce entrepreneurs to invert agriculture in order to create a long-term monetary economy.

\section{Conclusion}

The inadequate preparation of projects (NEB, SEB, etc.) by decision-makers and the numerous dysfunctions within the ministries involved give results far from the objectives envisaged in agricultural development and regional integration of the population of North Cameroon. The peasant lives in a precarious state and remains in food subsistence. Food security is still a major concern in the Far North where subsistence is still very high. Population density $(20-25 \mathrm{~km} 2)$ in rural areas relative to the resources adds to the problem of land. The lack of administration in land affairs reinforces 
traditional power. The economic future of North Cameroon will depend on large construction works, commercial networks in collaboration with the rest of Cameroon and with its neighbors like Chad, Central African Republic and Nigeria. Land tenure rights must be protected and guaranteed in the case of investment projects related to land management in order to build confidence.

\section{REFERENCES}

[1] Beauvilain, A.1989: Démographie. Institut des Sciences Humaines Yaoundé (CMR). 31p.

[2] Boutrais, J. (1971): « la colonisation des plaines par les montagnards au Nord-Cameroun (Monts Mandara) ». Paris O.R.S.TOM. $\mathrm{N}^{\circ} 24$.

[3] Boutrais, J. (1976): Compétition foncière et développement au Nord-Cameroun. La plaine de Mora. ONAREST-ISH Yaoundé. 45p.

[4] Boutrais, J. (1984): Le Nord-Cameroun: des Hommes, une région. Paris ORSTOM. Coll. Mémoire $\mathrm{n}^{\circ} 102,551 \mathrm{p}$.

[5] Ndembou, S. (1998): Le développement rural dans la plaine de la Bénoué (Cameroun): Changement géographique et permanence sociale. IRD-Paris 1. mémoire 574p.

[6] Ngo tama,A. C, Onana, J.,AsonGwed-Awa, A., Choupamon, J., Njehoya, A., Njoya A., (2007): Commercialisation des fourrages dans la zone Soudano-Sahélienne du Cameroun. In Revue Scientifique 2007 de l'IRAD, Palais des congrès Yaoundé 2-4 juillet. 45p

[7] Pontie, G. (1979):La contestation par la migration. Le cas des Guizigar du Nord-Cameroun cahier O.R.S.T.O.M série S.c humaines vol XVI, Nº : 1 et 2. 1979 pp 111 à 127.

[8] Roupsard,(1987). Nord-Cameroun, ouverture et développement thèse univer. Paris X , Nanterre, $512 p$.

[9] Seignobos C...2000, Sortir de l'oralité...

[10] Seignobos, C. (1996).Terroir de Siri : Terroir pionnier Tupuri dans la région de Touboro. ORSTOM. 120p.

[11] Seignobos, C. (1998). Le pays mundang, du «progrès » au « développement durable » DPGT.

[12] Seignobos, C. (2002).Trois acteurs du développement locale: le lamido, le maire, de la commune rural, et le sous-préfet. In : élément d'une stratégie de développement rural pour le Nord-Cameroun.

[13] Seignobos, C. et Teyssier, A. (1997). L'accélération de la crise foncière dans le Nord-Cameroun, DPGT/SODECOTON, ORSTOM, 3p.

[14] Seignobos, C. et Teyssier, A. (1998). Enjeux fonciers dans la zone cotonnière du Cameroun. In : Observatoire du foncier : MINAGRI, SODECOTON, ORSTOM. $\mathrm{n}^{\circ} 2,52 \mathrm{p}$.

[15] SODECOTON, 1975.Rapport de Synthèse des Campagne agricoles.

[16] Tchoue, G. (1983). Propagation de l'onde de crue de la Bénoué en aval de Lagdo. Rapport DGRST-CRH, Yaoundé Cameroun, 174p.

\section{AUTHOR's BIOGRAPHY}

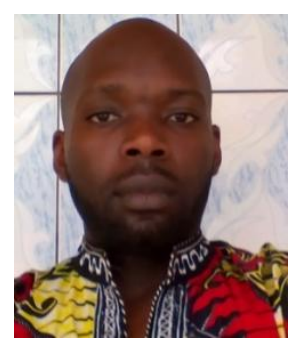

Sevidzem Silas Lendzele, and born in 1989 in Banso, Kumbo in the Bui Division of the North West region of Cameroon. I am a Researcher from the University of Dschang and i am currently involved in research activities in the domain of environment and agriculture. 